\title{
Új, laparoszkópos beültetésre alkalmas sérvháló állatkísérletes vizsgálata
}

\author{
Guba Péter Marcell \\ Semmelweis Egyetem, Általános Orvostudományi Kar, Kísérletes és Sebészeti Mútéttani Intézet, Budapest
}

\begin{abstract}
Bevezetés: A hálóval történő hasfal-rekonstrukció a sebészetben széles körben alkalmazott eljárás. A nem felszívódó hálók azonban számos komplikációt okozhatnak. Célkitüzés: Felszívódó, polimeralapú háló készítése, amely megfelelő kémiai, mechanikai és biológiai tulajdonságokkal rendelkezik. Módszer: A szerző háromdimenziós biokompatibilis, polivinil-alkoholból, reaktív electrospinninggel készült hálót használt. A toxicitási és sejt-háló kölcsönhatási vizsgálatok humán tüdőcarcinoma epithelialis sejteken (A-549), az in vivo vizsgálatok pedig 42 hím Wistar patkányon történtek a posztoperatív 1-5., 7. és 14. napon (3 patkány/csoport). Eredmények: Az in vitro kísérletekben a polivinilalkohol biokompatibilisnek bizonyult, az in vivo kísérletekben a belőle készült háló vizsgálata során a hálóval összefüggésbe hozható major komplikáció nem fordult elő. Következtetések: Megállapítható, hogy ez a polimerháló szövetbarát, a környező szöveteket nem károsítja, azokkal jól integrálódik. Orv. Hetil., 2016, 157(5), 180-184.
\end{abstract}

Kulcsszavak: hasfali sérv, sebészeti háló, polivinil-alkohol

\section{A novel surgical mesh suitable for laparoscopy studied on animal model}

Introduction: Reconstruction of the abdominal wall with mesh is a widely used surgical procedure. The non-absorbable meshes tend to cause numerous side-effects. Aim: The aim of the author was to produce an absorbable, polymerbased mesh that possesses appropriate chemical, mechanical and biological properties. Method: A three-dimensional, biocompatible mesh was produced from poly-vinyl-alcohol using reactive electrospinning. Toxicity and cell-mesh interactions were tested using human lung carcinoma epithelial cells (A-549), and in vivo tests were conducted in 42 male Wistar rats at the $1-5,7$ and 14 postoperative days ( 3 rats/groups). Results: In the in vitro tests poly-vinyl-alcohol was biocompatible. In the in vivo tests no major complication was associated with the mesh made of poly-vinylalcohol. Conclusions: The author concludes that this polymer mesh is biocompatible, it does not damage the surrounding tissues and integrates well with them.

Keywords: abdominal hernia, surgical mesh, poly-vinyl-alcohol

Guba, P. M. [A novel surgical mesh suitable for laparoscopy studied on animal model]. Orv. Hetil., 2016, 157(5), $180-184$.

(Beérkezett: 2015. november 9.; elfogadva: 2015. december 3.)

\section{Rövidítések}

GDA = glutáraldehid; PVA = polivinil-alkohol

A sérv a hasfal bármely részének gyengesége vagy folytonosságának megszakadása, a hasfali bemetszéssel járó mütétek után 10\%-ban alakul ki. Az ilyen esetek egyik megoldása a sebészi hálók alkalmazása lehet, ilyenkor a hagyományos sebellátással szemben jelentősen csökken a posztoperatív morbiditás, a recidívaarány és a gyógyulási idő $[1,2]$.

A nem lebomló polipropilén hálót több mint 50 éve használják [3]. A praeperitonealis elhelyezéssel szemben ezek intraperitonealis alkalmazása sok komplikációval jár, 
például fistulák és infekciók, adhéziók kialakulása, a háló kimozdulása és krónikus fájdalom [4]. A hasüregi adhézió olyan patológiás összenövés, ami jellemzően a cseplesz, a vékony- és vastagbelek, a hasfal és más hasüregi szervek között található meg $[5,6]$.

Néhány részlegesen és teljesen felszívódó hálótípus elérhető. A kisebb mennyiségű idegen test és a kevesebb idő, amelyet a hasüregben tölt, kevesebb szövődménnyel jár [7]. A felszívódó hálók beültetése jó eredményeket mutat [8]. A pozitív tapasztalatok és a szövődmények ismeretében megfogalmaztuk az elvárásainkat: az ideális sebészeti háló biológiailag lebomló, rugalmas, nem okoz adhéziót, biokompatibilis és lebomlása során nem képez toxikus metabolitokat. Erre a feladatra a polimerekből készült nanoszálak ígéretesnek tűnnek.

A polimeralapú hálók pórusos szerkezetűek, így képesek arra, hogy utánozzák az extracelluláris mátrixot. Kutatásunk célja, hogy megtaláljuk az ideális hálót, amelynek felszívódása szövődménymentes, és megjósolható ideig tart. A vizsgálatokat saját fejlesztésü, nanotechnológiával készített polivinil-alkohol (PVA) hálókkal végeztük.

\section{Módszer}

A PVA hidrofil, nem toxikus és biológiailag lebomló polimer. A nanoszálak elkészítésére számos módszer létezik, például az általunk alkalmazott electrospinning (1. ábra).

\section{Az electrospinning folyamata}

Elektromos teret hoztunk létre egy polimeroldat és egy gyưjtőfelület között. Egy fecskendőben található az oldat, amit ennek nyílásánál a felületi feszültség egy csepp formájában tart. Felszínét az elektromos mező feltölti. Ahogy az elektromos tér intenzitása növekszik, a fecskendő végén a csepp megnyúlik és kialakul a Taylor-tölcsér. Amikor a töltött részecskék taszító ereje meghaladja a felületi feszültséget, egy oldatnyaláb hagyja el a tölcsér tetejét, ennek átmérője a levegőben csökken. Emiatt a felületi töltéssűrűség megnő, és a kezdeti szál számos apróbb szálra oszlik, amelyek összegyúlnek a gyújtőfelszínen, egy véletlenszerü elrendeződésü, nanométeres vastagságú szálakból álló hálózatot alkotva [9]. Az 1. ábra mutatja a berendezés sematikus elrendezését.

A nanoszálak készítése PVA-ból olcsó módszer [10]. A PVA-t vízben oldottuk $90{ }^{\circ} \mathrm{C}$-on két óra alatt, és további 30 percig pihentettük, hogy biztosítsuk a homogenizációt. Koncentrációja 5-15 tömegszázalék volt. A PVA egy földelt gyüjtőfelület felett volt felfüggesztve egy kapillárisban. A feszültség rákapcsolásával szálakra szakadt, ezek a gyújtőfelülethez vonzódtak. Az elektromos erők több ezerszeres mértékben nyújtják meg a szálakat, amelyek így a textilszálaknál egy-két nagyságrenddel vékonyabbak lesznek [11], emiatt a felület-tömeg arány nagy lesz. Végül az oldószer elpárolog, és a szálak meg- szilárdulnak. Az eredményül kapott nanoszálak szabálytalan szerkezetú szövetet alkotnak (2. ábra, bal oldal), ez kompakt, körülbelül $1 \mathrm{~mm}$ vastagságú (2. ábra, jobb oldal). A hálót beültetés előtt $\mathrm{ClO}_{2}$-oldattal sterilizáltuk [12].

\section{In vitro vizsgálatok}

In vitro tanulmányainkban a PVA-háló lebomlásakor keletkező molekulák toxicitását, illetve a háló-sejt interakciót vizsgáltuk humán tüdőcarcinoma epithelialis sejteken (A-549). Először különböző koncentrációjú $\left(10^{-8}-0,8 \mathrm{~g} / 100 \mathrm{~g}\right)$ PVA-oldatok biokompatibilitását mértük. Az oldatot médiumban áztatott PVA-hálóból és glutáraldehidból készítettük (GDA), majd összekevertük a médiummal, mielőtt sejteket helyeztünk bele. A GDA crosslinker szerepet tölt be, a polimer vízben való oldásának elkerülésére.

A következő kísérletben a sejtek tapadását és morfológiáját figyeltük PVA hidrogél jelenlétében. A hidrogél elkészítéséhez PVA-oldatot, GDA-t és desztillált vizet használtunk, a gélképződést $2 \mathrm{M}$-os sósavoldattal indukáltuk. A hidrogéleket Petri-csészébe helyeztük, és a sejteket a felületükre oltottuk. 192 órás inkubálást követően inverz mikroszkóppal vizsgáltuk a mintákat, a változásokat fotókkal dokumentáltuk (Olympus CK2).

Végül a PVA-hálókat, amelyeket a médiumban (DMEM 6546, Sigma Aldrich) 24, 48, 72, 96 és 168 órán át inkubáltunk; 10\% fetal calf serum (Kvalitex), 4\% L-glutamin (Life Technologies) és gentamicin (Sandoz) $\left(37^{\circ} \mathrm{C}, 5 \% \mathrm{CO}_{2}\right)$ hozzáadása után 24 lyukú plate-eken tanulmányoztuk (Sarstedt). A hálókat $2 \mathrm{M}$ sósavoldattal előkezeltük és $\mathrm{ClO}_{2}$-vel sterilizáltuk. A kísérletek azt is igazolták, hogy a $\mathrm{ClO}_{2}$ nincs negatív hatással a sejtek életképességére és osztódására, antibiotikus hatása pedig jól ismert [12]. A kontrollcsoportban A-549 sejteket helyeztünk el médiumban, hálók nélkül. A sejteket tripánkék festékkel vizualizáltuk, a fotók digitális fényképezőgéppel (DEM 130, Scope Photo szoftver) készültek.

\section{In vivo vizsgálatok}

A PVA vizsgálatára negyvenkét felnőtt, hím, albínó Wistar patkányt használtunk fel, amelyek tömege 200-250 g volt. Az állatokat itatóüveggel ellátott patkánykennelekben tartottuk, maximum négy állattal kennelenként, standard laboratóriumi körülmények között, és patkányoknak gyártott pellet formátumú tápot kaptak. Az állatokat $20-22{ }^{\circ} \mathrm{C}$-os hőmérsékleten tartottuk, 50-60\%os relatív páratartalomban és 12 órás világos-sötét ciklusokkal. A patkányokat véletlenszerúen választottuk ki és 10 csoportra osztottuk óket. Az összes kísérlet a saját kutatócsoportunk által kidolgozott protokoll szerint zajlott. Anaesthesiára ketamin/xylazin 4:1 térfogatarányú keverékét alkalmaztunk. Az állatkísérletet a Nemzeti Élelmiszerlánc-biztonsági Hivatal (NÉBIH) engedélyezte. 


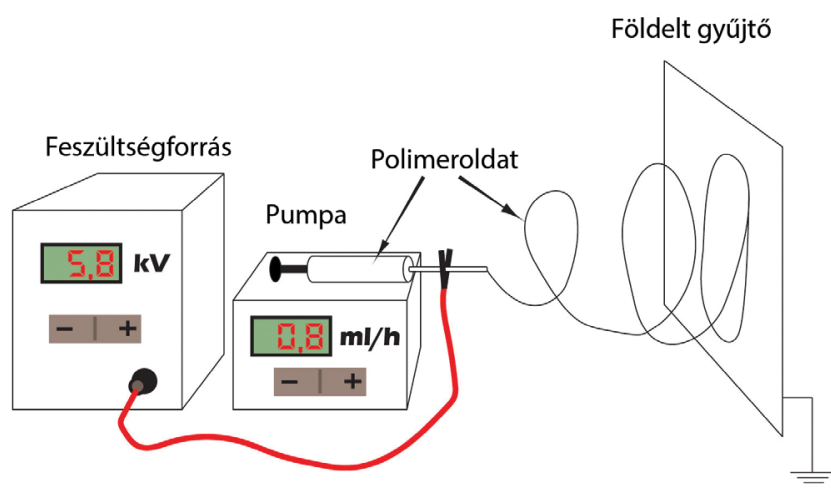

1. ábra

| A nanoszálkészítés sémás folyamata

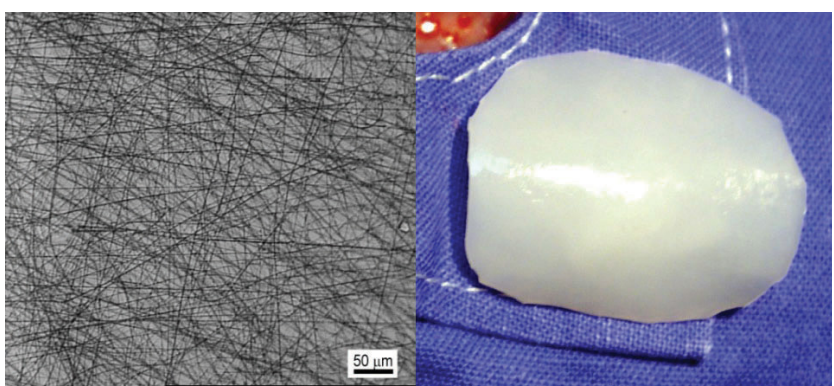

2. ábra

A nanoszálakból álló szövet szerkezete (bal oldal) és makroszkópos képe (jobb oldal)

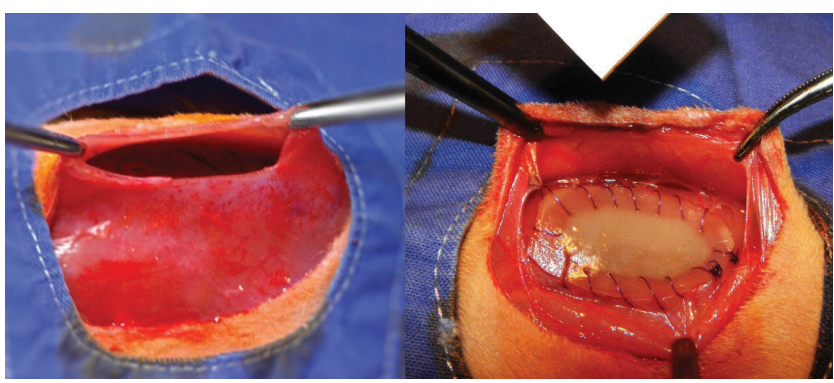

3. ábra

| Hasfali szövethiány lefedése PVA-hálóval

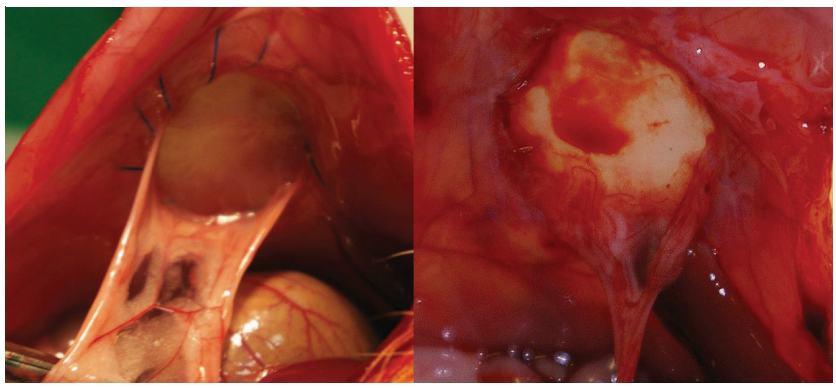

4. ábra | A mútéti terület képe a késői posztoperatív időszakban

A kontrollállatokon $(\mathrm{n}=15)$ egy $4 \mathrm{~cm}$-es medián laparotomiát végeztünk, majd kétrétegú zárást alkalmaztunk 3/0-s varróanyaggal. Reoperációra az $1 .(\mathrm{n}=3), 2$.

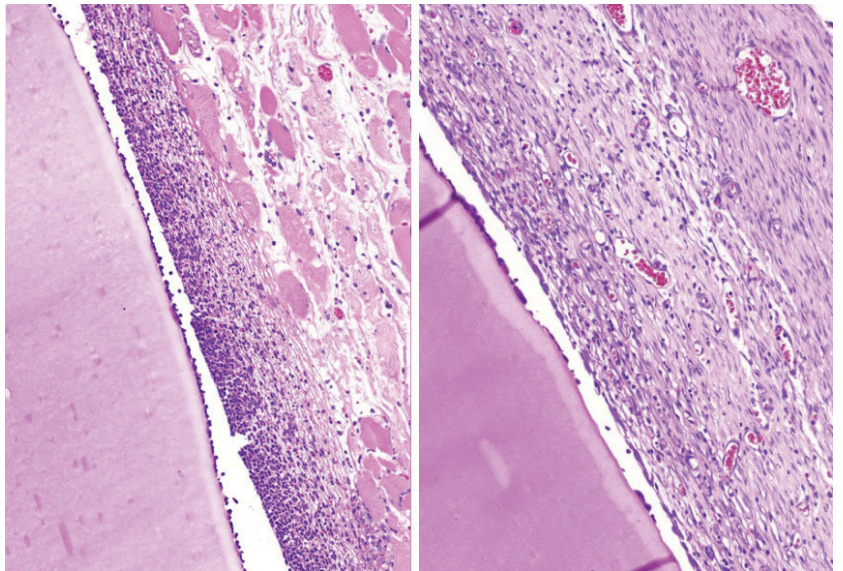

5. ábra | A beültetett háló környékének szövettani képe

$(\mathrm{n}=3), 3$. $(\mathrm{n}=3), 4$. $(\mathrm{n}=3), 5 .(\mathrm{n}=3), 7$. $(\mathrm{n}=3)$ és 14 . $(\mathrm{n}=3)$ posztoperatív napokon került sor. A keletkezett adhéziókat makroszkóposan értékeltük.

A sérvmodellben a bőr paramedián bemetszését követően a hasfal jobb oldalán egy szövethiányt hoztunk létre $(\phi \mathrm{d}=2 \mathrm{~cm})$. A hiányt PVA-hálóval fedtük le $(\phi \mathrm{d}=2,5$ $\mathrm{cm})$, a hálót pedig egyszerú tovafutó varrattal rögzítettük, adhezív, nem felszívódó polipropilén varróanyaggal (4/0) (3. ábra). A bört egyszerú csomós varrattal zártuk be (3/0-s varróanyag).

Az állatokat az 1., 2., 3., 4., 5. és 7. posztoperatív napon termináltuk és vizsgáltuk a rövid távú, illetve a 14., 30. és 90. posztoperatív napon a hosszú távú értékelés céljából. Mindegyik csoportban 3 állat volt. A paramedián feltárás után leírtuk az adhéziók helyét és tulajdonságait [13]. Az adhéziókat leválaszthatóság, alak és méret szerint értékeltük (a Diamond-klasszifikációhoz [14] nagyon hasonló, saját rendszer szerint).

Az alak megállapítása az összetapadt felszín kétdimenziós mérésével történik, az alábbi kategóriák szerint: szálagos (az összetapadt felszín kisebb, mint $0,5 \times 0,5 \mathrm{~cm}$ ), függönyszerú (az összetapadt felszínek hossza $>0,5 \mathrm{~cm}$, de szélessége $<0,5 \mathrm{~cm}$ ) és nagy kiterjedésű (az összetapadt felszínek nagyobbak, mint $0,5 \times 0,5 \mathrm{~cm}$ ).

$\mathrm{Az}$ adhézió leválaszthatóságának értékeléséhez az adhéziókat erősségük szerint három csoportba osztottuk: instabil, közepesen stabil, stabil. Instabil adhéziók esetén a felszínek a reoperáció és a mintavétel során könnyen, esetleg maguktól elválnak egymástól. A közepesen stabil adhéziók a reoperáció és a mintavétel során összetapadva maradnak, de közepes húzással nagyobb szövetroncsolás vagy vérzés nélkül elválaszthatóak. A stabil adhéziókat még erős húzással sem lehet elválasztani egymástól, csak éles preparálással és súlyos vérzés veszélye mellett. A lokális reakciót makroszkóposan és szövettanilag is értékeltük. A célunk az volt, hogy a biokompatibilitást a korai és a késői adhéziós, gyulladásos és kötőszöveti válaszreakciók mérésével értékeljük. 
A szövettani mintákat 10\%-os formaldehidoldattal fixáltuk, paraffinba ágyazták, és kézzel metszették (vastagság $4 \mu \mathrm{m})$. A metszeteket hematoxilin-eozin (HE) festéssel festették, kézzel, csoportokban, majd Pannoramic Scan (3DHISTECH, Budapest, Magyarország) rendszerrel digitalizálták, Plan-Apochromat 20-szoros nagyítású objektívvel, 1,6 × kameraadapter-nagyítással és $1 \times$ Optovar nagyítással, CIS VCC-FC60FR19CL kamerával. Ez az összeállítás 0,24 $\mu \mathrm{m} /$ pixel felbontást eredményezett. Az így digitalizált teljes metszeteket Pannoramic Viewer (3DHISTECH, Budapest, Magyarország) szoftverrel vizsgálták. A hálóval szemben kialakult gyulladásos reakciót a típusa és intenzitása alapján értékeltük.

\section{Eredmények}

24 óra elteltével a sejtek normális morfológiával rendelkeztek a PVA-oldatban, a hidrogél felszínén nem találtunk sejteket. 72 órát követően a sejtek a Petri-csészében levő oldatban konfluensek voltak, és a hidrogél jelenlétében is a sejtvonalra jellemző alak volt látható.

A hálókat 24 lyukú plate-eken vizsgáltuk. Itt a tapasztalatok azt mutatták, hogy a sejtek nem tapadnak a háló felszínére, de a plate-ek alján csoportokban felfedezhetôk voltak.

Három sérvmodellpatkányt idő előtt terminálni kellett a háló elmozdulása miatt. A vizsgálat ideje alatt fertőzést nem találtunk. Öt állatban kevés serosus folyadékot fedeztünk fel a háló és a bőr között az 1. $(\mathrm{n}=1), 2$. $(\mathrm{n}=2)$ és a $3 .(\mathrm{n}=2)$ posztoperatív napon.

A bőr eltávolítása után láthatóvá vált, hogy a háló jól integrálódott a környező szövetekbe. A sérvmodellcsoportban 4 szálagos, 17 függönyszerü és 6 nagy kiterjedésû adhéziót találtunk, többségük $(\mathrm{n}=19)$ a varrathoz tapadt és csak kevés $(\mathrm{n}=5)$ a hálóhoz, utóbbiak minden esetben kevesebb mint a felszín egyharmadát borították be. Az adhéziókat alkotó fó szerv a nagycseplesz volt, de közelsége miatt néhány $(\mathrm{n}=6)$ alkalommal a máj is részt vett a kialakításukban.

$\mathrm{Az}$ adhéziók tartósságát a mintavétel közben enyhe vagy erős húzással értékeltük. Az adhézió 6 esetben volt instabil, fóleg a korai posztoperatív (1-3.) napokban. Erősebb húzás kellett a közepesen stabil adhéziók ( $\mathrm{n}=$ 13) szétválasztásához, ami a 3-5. posztoperatív napon dominált. Nyolc esetben találtunk stabil adhéziót, ahol még erős húzásra sem váltak el egymástól az összetapadt felszínek, ez fóleg a késői posztoperatív szakban volt jellemző (4. ábra).

A kontrollcsoportban nem volt jellemző az adhézió. Mindössze két állatnál találtunk függönyszerű adhéziót, mindkét esetben a cseplesz tapadt keskeny vonalban a metszéshez.

A PVA-háló és a peritoneum közötti interakciót a mintákon patológus vizsgálta. A beültetett háló környékén az első néhány napban várható mértékű akut gyulladásos reakció volt jelen, ami nem különbözött számottevően a kontrollállatokon a metszés környezetében tapasztalt gyulladástól (5. ábra, bal oldal). A hosszabb távú megfigyelések során azt láttuk, hogy a háló környezetében a gyulladás lecsillapodott, és akadálytalanul megindult a hegképződés (5. ábra, jobb oldal). A vizsgálat során a hálóval összefüggésbe hozható óriássejtes granulomát nem találtunk, a háló szerkezetét épnek találtuk. Így megállapítható, hogy a polimer háló szövetbarát, biokompatibilis, a környező szöveteket nem károsítja, azokkal jól integrálódik.

\section{Megbeszélés}

A tanulmány célja a polivinil-alkohol (PVA) sérvháló orvosbiológiai viselkedésének értékelése volt. Ebben az áttekintésben egy új, electrospinninggel készült 3D hálót vizsgáltunk mind in vitro, mind in vivo tesztekkel. Az in vitro eredmények szerint a sejtek a PVA oldatában és a PVA hidrogél jelenlétében is képesek voltak a szaporodásra. A PVA-háló és bomlástermékei semmilyen toxikus hatással nem voltak az A-549 sejtekre, ezek normális morfológiát mutattak a jelenlétében, viszont a háló felszínére nem tapadtak ki, ami azt jelzi, hogy a PVA nem adhezív.

Állatkísérleteinkben a PVA-hálót hasfali sérv rekonstrukciójára használtuk, megvizsgáltuk a hatékonyságát, adhéziógeneráló hatását és a gyulladásos választ. Hosszú távú kísérletünkben szignifikánsan több kitapadást találtunk a varratokhoz, mint a háló felületéhez.

A szövettani megfigyelések szerint a hálók a szerkezetük megtartása mellett beépültek a környező szövetekbe. Idegentest-granulomát nem találtunk, ami alátámasztja az in vitro kísérletekben tapasztalt biokompatibilitást.

\section{Következtetés}

Kijelenthető, hogy a PVA-háló biokompatibilis és alkalmas a további vizsgálatra. A mesterséges szövetpótlás a jövőben alternatívát nyújthat a szövet hiányának vagy funkcióvesztésének jelenlegi terápiás megoldásaira.

Anyagi támogatás: Ezt a kutatást az OTKA K 105523. finanszírozta.

A szerző a cikk végleges változatát elolvasta és jóváhagyta.

Érdekeltségek: A szerzőnek nincsenek érdekeltségei.

\section{Köszönetnyilvánítás}

Köszönöm Prof. Dr. Wéber György intézetvezető úrnak, hogy lehetővé tette a kutatást, és személyesen is támogatott a munkában. Köszönöm továbbá Dr. Szabó Györgyinek, Fehér Daniellának, Dr. Csukás Domokosnak, Dr. Juhos Krisztinának, Vódliné Schum Ibolyának és Szentes Péternek a segítséget. Külön köszönet Molnár Kristófnak, aki a hálókat a Semmelweis Egyetem Biofizikai és Sugárbiológiai Intézetének Nanokémiai Kutatócsoportjában készítette. 


\section{Irodalom}

[1] Bageacu, S., Blanc, P., Breton, C. et al.: Laparoscopic repair of incisional hernia: a retrospective study of 159 patients. Surg. Endosc., 2002, 16(2), 345-348.

[2] Mariette, C., Wind, P., Micelli Lupinacci, R., et al.: Practice patterns in complex ventral hernia repair and place of biological grafts: a national survey among French digestive academic surgeons. J. Visc. Surg., 2014, 151(1), 9-16.

[3] Novitsky, Y. W., Harrell, A. G., Hope, W. W., et al.: Meshes in hernia repair. Surg. Technol. Int., 2007, 16, 123-127.

[4] Halm, J. A., de Wall, L. L., Steyerberg, E. W., et al.: Intraperitoneal polypropylene mesh hernia repair complicates subsequent abdominal surgery. World J. Surg., 2007, 31(2), 423-430.

[5] Cheong, Y. C., Laird, S. M., Li, T. C., et al.: Peritoneal healing and adhesion formation/reformation. Hum. Reprod. Update, $2001,7(6), 556-566$

[6] Kössi, J., Salminen, P., Rantala, A., et al.: Population-based study of the surgical workload and economic impact of bowel obstruction caused by postoperative adhesions. Br. J. Surg., 2003, 90(11), 1441-1444.

[7] Bellón, J. M., Rodríguez, M., García-Honduvilla, N., et al.: Partially absorbable meshes for hernia repair offer advantages over nonabsorbable meshes. Am. J. Surg., 2007, 194(1), 68-74.

[8] Agresta, F., Baldazzi, G. A., Ciardo, L. F., et al.: Lightweight partially absorbable monofilament mesh (polypropylene/poliglecaprone 25) for TAPP inguinal hernia repair: initial experi- ence. Surg. Laparosc. Endosc. Percutan Tech., 2007, 17(2), 91-94.

[9] Tsukruk, V. V., Reneker, D. H.: Periodic surface instabilities in stressed polymer solids. Phys. Rev. B Condens. Matter, 1995, 51(9), 6089-6092.

[10] Kenawy, E. R., El-Newehy, M. H., Abdel-Hay, F. I., et al.: Synthesis and biocidal activity of modified poly(vinyl alcohol). Arabian J. Chem., 2014, 7(3), 355-361.

[11] Ziabari, M., Mottaghitalab, V., Haghi, A. K.: Application of direct tracking method for measuring electrospun nanofiber diameter. Braz. J. Chem. Eng., 2009, 26(1), 53-62.

[12] Noszticzius, Z., Wittmann, M., Kály-Kullai, K., et al.: Chlorine dioxide is a size-selective antimicrobial agent. PLoS ONE, 2013, $8(11), \mathrm{e} 79157$

[13] Zublke, H. V., Lorenz, E. M., Straub, E. M., et al.: Pathophysiology and classification of adhesions. Langenbecks Arch. Chir. Suppl. II. Verh. Dtsch. Ges. Chir., 1990, 1009-1016.

[14] Diamond, M. P., Freeman, M. L.: Clinical implications of postsurgical adhesions. Hum. Reprod. Update, 2001, 7(6), 567-576.

(Guba Péter Marcell, Budapest, Nagyvárad tér 4., 1089 e-mail: gmarci90@gmail.com) 